\title{
An Evaluation of Electronic Commerce in Terms of Accounting Information System in the Global Competitive Environment
}

\author{
Prof. Dr. Naim Ata Atabey (Selçuk University, Turkey) \\ Ph.D. Candidate Fatma Özlem Y1lmaz (Selçuk University, Turkey) \\ Assoc. Prof. Dr. Baki Yılmaz (Selçuk University, Turkey)
}

\begin{abstract}
The gradually increasing of the competition among the managements that operate in the present-day global competitive environments leads to the speedily and continuously development of the information technologies in the managements. The electronic commerce (e-commerce), which is one of the most dynamic ways of the competition and emerges as a result of the speedily and continuously developments in the information technologies, starts the process of increasing the competition, the flexibility, the quality and the speed among the managements by providing that all sorts of operations, which belong to the commercial activities and interest in both organizations and individuals, are made on the electronic environment. E-commerce makes some changes in the management processes and their operations, and these changes affect on the assets and the sources of the managements, and it causes to incomes and expenses and brings the events and the operations, which had to be explained in the financial tables, into the forefront. E-commerce, therefore, shows itself up as a part of Accounting Information System with its way affecting on the processes and the operations in the managements. E-commerce, in this Study, has been tried to assess by the perspective of Accounting Information System in the global competitive environment.
\end{abstract}

\section{Introduction}

By the passing in the information society, the developments in the information and communication technologies have transformed the world into, with the word of McLuhan, "a big village." This transformation has encountered the managements, which operate across the world, with the new opportunities, particularly. These opportunities have been affected in the structure of economic activities, especially.

The globalization discussions bring with many economical, political, cultural, and social openings. The most important concept coming to the forefront with these discussions is "the phenomenon of competition." Competition is the concept that clearly expresses the change in the present day (Sevim, 2009).

The structure of economic activities in the global competitive environment has been changed radically in parallel to the development process of information technologies. This process of change has increased the use of electronic technologies in the birth of information and in its transferring and producing.

At the present day, by the removal of the usages based on the face-to-face and written recording system and of the trade barriers put forward by the concepts of distance-time, it leaves its place to the process of the electronic/web-based data processing in increasing gradually. By the effect of technological developments, a great number of serious changes, from the forms of production to the forms of distribution and from the forms of usage to the methods of reaching the customers, are lived in the fields that managements operate. E-commerce, in this process, has come to be the form of a new and great trade channel in the commerce by providing a possibility to the trading (buying and selling) of both many imaginary goods and traditional physical goods, especially with the using of Internet in the international commercial operations. The activities of traditional marketing and customer relations almost in all the sectors at the present day have been rearranged as it will be benefitted from some conveniences like marketing, reaching the information, and decreasing the cost that Internet provides (Seyidoglu, 2000).

The electronic commerce has become a powerful instrument of distribution and trade, increasing progressively in the present times. That the distributional and commercial operations are made in an electronic environment leads to the necessity that the electronic commerce is evaluated with the perspective of accounting by affecting especially on the accounting applications together with other managerial processes.

In our Study, firstly it has been given the general information concerning with the electronic commerce and then evaluated the electronic commerce in terms of Accounting Information System.

\section{Electronic Commerce and its Scope}

The technological developments lived by the increasing of global competition and the changing of the understanding structure of information system management of managements have forced the managements to be more innovator, more productive, more flexible, and more dynamic, affecting on them considerably. These developments have made the electronic commerce an important instrument of trade by enabling that information, 
documents, data, and records, which are necessary for commercial activities, are transferred into an electronic environment and that the operations can be made in this environment.

E-commerce, which can be defined as the purchase and sale of goods and services and realized by a medium of exchange between two sides and emerges as a result of being made by an instrument in an electronic environment, can be described in many ways.

Electronic Commerce (WTO, 1998; Carter, 2002; ETicaret 2009);

- World Trade Organization (WTO): "The producing, advertising, selling, and distributing of goods and services by the telecommunication networks."

- Organization for Economic Cooperation and Development (OECD): "All commercial operations, which interest in persons and establishments and base on processing and conveying a written text got numerical, a voice, and an image."

- $\quad$ United Nations Centre for the Facilitation of Procedures and Practices for Administration, Commerce and Transport (UN-CEFACT): "The business information, which is structured and unstructured to be directed the activities of business, management and consumption, is shared on electronic instruments between producers, consumers, public establishments, and other organizations."

- Wurman and et al. have defined the electronic commerce as the unity of activities that uses the electronic communication channels in the stock, exchange, advertisement, distribution, and payment of services and products and as a system that the steps of meeting, agreeing, and realizing among the ones concerned are automatized (Wurman and et al., 1998).

- Electronic commerce is the making of producing, advertising, selling, paying, and distributing of the products by computer networks (Schoop, 2005). By the electronic commerce, trading of goods and services, designing of product, producing, marketing, advertising, presenting, ordering, making an agreement, banking operations, fund transferring, engineering services, public acquisition, coining electronic money (imaginary money), (stock) exchange operations, e-notaryship, transferring of intellectual property rights, and renting operations etc. are made (Bozkurt, 2000).

- The Electronic Commerce Coordination Commission in Turkey has defined the electronic trade as "the whole of the commercial operations, which bases on the processing, conveying, and keeping of the numerical information in the form of writing, voice, and image in the environments of the open network (Internet) of individuals and establishments or the closed-network that can be reached by a limited number of users and which aims at constituting a value" (ETKK, 1998; Parlakkaya, 2005).

- Electronic commerce is to use systematically the developments in the link networks and communication technology to develop the ways of interaction with suppliers, customers, shareholders, investors, and all the concerned persons and people of a company (Alagoz, 2007).

By the development of the concept of 'electronic commerce', computer systems, databases, and various electronic systems have led that the electronic commercial applications have become widespread and that a lot of changes have occurred in these ways by these applications have also contained some cultural, social, and economical fields.

Electronic commerce can be defined as plying a trade with an instrument or as a form of trade in an electronic environment. Any electronic operations resulting commercially are included in the scope of e-commerce. Electronic commerce contains all the activities concerning with the designing, producing, advertising of product, commercial transactions, and the paying on the account by all sorts of computer networks (ETicaret, 2009). Electronic commerce, by its dimension in this point, has a wide scope such the purchasing of goods and services, the instantly distributing of numerical content, the electronic fund transfer, the commerce of electronic share, the electronic bill of lading, the electronic auction, the joint designing and engineering, the instantly presentation from the source, the public acquisitions, the direct marketing to consumer, the services after sale, and the making of payments digitally (Ozbay and Devrim, 2000; Parlakkaya, 2005).

Electronic commerce, in an organizational and individual level, includes the operations related to all commercial activities. All the numerical data produced, processed, and conveyed in this field bases on the processing and conveying of texts, voices, and visual images. Among some important matters in this field, there are protection of consumers; competition; systems of finance and payment; taxation; the intellectual, industrial, and commercial property rights; security; legal regulations; and the mechanism of settling disputes (Canpolat, 2001).

Such every kind of information in electronic commerce is transferred from any place to another place of the world in seconds in an electronic environment is a revolution by itself, it has also a different importance because it has a potential to be able to accelerate other revolutions and to change every dimension of humanity's life fast (Sahin, 2008). 


\section{Instruments and Models of Electronic Commerce}

The instruments, which provide that electronic commerce can be made, can be lined up like this:

- Telephone

- $\operatorname{Fax}$

- Internet

- Television

- Computer

- Electronic (Cashless) Transfer and Money Transfer Systems

- Electronic Data Exchange (Transfer)

- Telecommunications

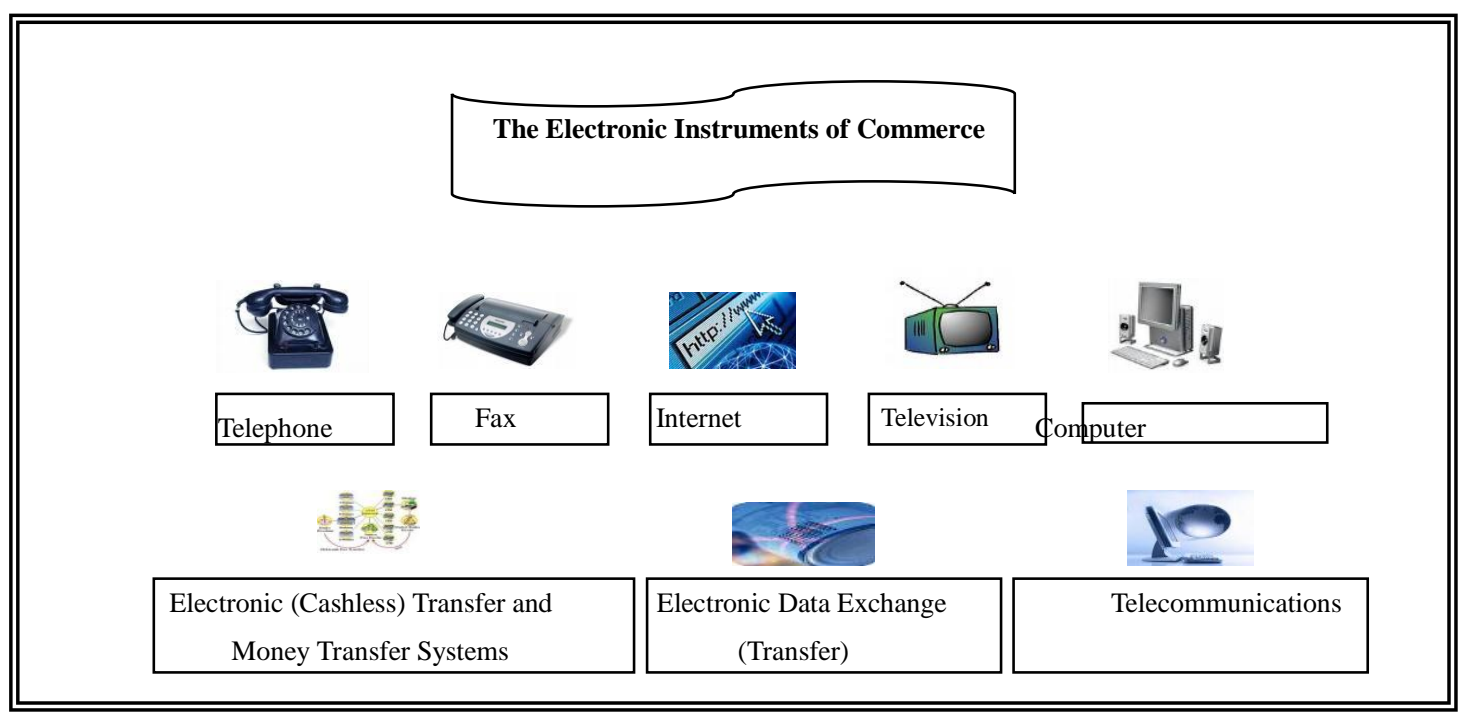

Figure 1. The Electronic Instruments of Commerce

- Telephone, fax, and television are the traditional electronic instruments of commerce. Telephone is used to provide intercom unication between a buyer and a seller; fax to transfer a document; and television to advertise and present the products (Parlakkaya, 2005). By television connects to Internet, the user starts to be able to ply an electronic trade (Ozbay and Akyazı, 2004).

- Because Electronic (cashless) transfer and money transfer systems are used in the electronic commerce, they make the electronic commerce easier significantly and become an inseparable part of it. However, because Automated Teller Machines (ATM) and credit, bank, and smart cards are used only in money transfers, these have a limited function in the trade (Yenigun, 2003).

- Electronic data transfer, as a system that provides documents, information, and data exchange by computer networks between two commercial managements, is one of the instruments of electronic commerce.

- Internet becoming an inseparable and a basic instrument, which develops speedily in the present day, of ecommerce is a commercial instrument providing a multi-directional communication, and the transactions (and operations) can be performed so fast in the computer environment thanks to Internet (Canbolat, 2001).

- Telecommunication setting up the substructure of electronic commerce is one of the classical but important instruments, which raises the information sharing upmost and provide its extensity.

The electronic commercial instruments, which make the transactions of the sides that ply a trade in an electronic environment easier and speedier, are continuously renewed as tied to the development of technology in the present day.

The models of electronic commerce can be lined up like this (Zerenler, 2007):

- Management-to-Management Electronic Commerce

- Customer-to-Customer Electronic Commerce

- Internal Electronic Commerce

- Consumer-to-Consumer Electronic Commerce

- Electronic Commerce from State to Consumer and Management

- Interstate Electronic Commerce

- Electronic Commerce According to the Attribute of a Product 
Management-to-management electronic commerce is a commercial model that is done as an information exchange, which the managements develop on Internet together with buyers, suppliers, and other concerned persons for their buying and selling operations (Trepper, 2000).

Customer-to-customer electronic commerce is a commercial model that contains the operations of directly selling various products to customers by using some electronic instruments.

Internal electronic commerce is a commercial model that is done among management units and that includes a workflow application.

Consumer-to-consumer electronic commerce is a commercial model that consumers buy and sell some their own products among themselves under some conditions and by a management instrument.

Electronic commerce from State to consumer and management is a commercial model that includes the realization of the aim at "reaching" all the relations between public establishments and citizens to "a more management" (Torres and at al., 2005) with information and communication technologies.

Interstate electronic commerce is a commercial model that is done in an electronic environment for importing and exporting between public establishments and other public establishments in other countries.

Electronic commerce according to the attribute of a product can be evaluated in two groups as directly and indirectly (Zerenler, 2007). While the ordering and advertising of a product in the indirect commerce are made in an electronic environment, the delivery of product is done via cargo and post in harmony with traditional ways. As for the delivery of product in the direct commerce is completely realized in an electronic environment.

\section{Accounting Information System and Electronic Commerce}

Accounting Information System is the most important and the oldest of the basic managerial information systems (Surmeli, 1994). Accounting Information System is a system that produces information, which explains the formation of sources of an organization, the form of using of these sources, the increases and the decreases occurring in these sources in consequence of the activities of the organization, and the condition of the organization in terms of finance, and that conveys them to the concerned persons and establishments. This process operates towards the objective of providing on the time the true and reliable information related to assets, sources, and results of activity with the aim of those in the position of decision-making are able to take consistent decisions (Atabey and et al., 2006).

\begin{tabular}{|c||ll|l|}
\hline \multicolumn{1}{|c|}{ INPUT } & PROCESS & \multicolumn{1}{|c|}{ OUTPUT } \\
\hline $\begin{array}{c}\text { Information } \\
\text { and } \\
\text { Documents }\end{array}$ & $\begin{array}{l}\text { Commercial } \\
\text { Books }\end{array}$ & Balances \\
\hline
\end{tabular}

\section{Figure 2. The Flow of Accounting Information-Financial-Qualified Event and Operations Source: Surmeli,
1994.}

As seen in Figure 2, the Flow of Accounting Information that is related to the activities of a management follows the flow of input, process, and output as is in every system.

The financial-qualified events occurring in the managements lead to be lived a change on the structure of assets and sources and on the activity results of the management. In this way, the field of interest of Accounting Information System consists of financial-qualified events and operations that emerge in the management. In Account Information System, that information becomes reliable, well-timed, neutral, understandable, and consistent makes it more useful and beneficial (Karasioglu, 2001).

It is indisputable that Account Information System, which is the most important in terms of managements, has to accord with economical and technological developments. The electronic volume of trade, in the present day, speedily spills over the whole world in the leading of multinational American companies (Karatas and Yilmazsoy, 2001). The firms plying electronic trade use the basic principles and the rules of accounting that the firms trading in traditional ways will use. In this way, the accounting order used in the traditional trade will be valid also for electronic commerce, and it will be used (Semerci, 2007).

The management processes of electronic commerce and the changes that they make in their operations will affect on the accounting systems, inevitably. E-commerce has not only changed the form of trade but also constituted some concepts like electronic billing and electronic archiving that affect on Accounting Information System in the managements (Parlakkaya, 2005). The making of commercial books and the constituting of 
financial statements in the electronic environments enable to be lived a change for things like fastness of business, highness of rate of truthiness, and savings of paper and stationery (Yukcu and Gonen, 2009).

The important problem, which electronic commercial applications lead in terms of Accounting Information System, is that the order of document in the input process of the system is electronic and that some legal regulations concerning with it are not done adequately and that in this way it is seen different applications are done (Y1ldiz and Canbaz, 2008).

By the perspective of Accounting Information System in the managements, it is possible to sum up the effects of electronic commercial applications like this:

- The presentation in digital environments of financial-qualified events and operations, the base of Accounting Information System, will broaden the effects of electronic commercial applications more.

- In a management, in the case of the broadening of electronic commercial applications, managers will be able to obtain the information that they need, at the right time and at will, because all financial information related to a management is more regular and easily accessible.

- In the degree of accuracy and consistency of the decisions on which the future financial informational predictions and managerial plans of managers of managements base, an increase will be lived.

- The financial structures of the managements plying an electronic commerce will be more effective in comparison to other managements.

- Because information is conveyed very speedily, the flow of accounting information will be reached more effectively and fruitfully to the concerned sides.

- The forms of delivery and payment in an electronic commercial operation and the computer programs used in a management will make the applications of Accounting Information System easier.

- Electronic commercial applications will lead to a considerable decrease in the number of accounting documents and in the costs.

- For the order of document(s) and record(s), it will be provided new programs are developed.

- The demand for the accountants using electronic commerce will increase (Akkas, 2000).

- The goal of providing true and reliable information related to assets, sources, and results of activity at the right time will increase the reliability of electronic commerce.

\section{Conclusion}

The dynamic power of globalization is the fast developments in that information and communication technologies. These developments determine the form of trade, the understanding, and the application of the digital era, especially with electronic commercial applications. The phenomenon of competition, together with the phenomenon of globalization lived in the world, increases (its weight) as days pass; the demand periods of products gradually decrease because the products, which are presented in proper to the consumers' personal needs and expectations, are demanded; and the kind of product grows speedily. Managements, as a result of these developments, are in the position of supplying a great variety of products to the market with speed, with a relevant cost and with a level of quality at will, to be able to provide a competitive advantage. The electronic commercial applications providing this state are an important operation instrument of the new models of economy and management. The electronic commercial applications, which continuously renew with information and communication technologies, enable that the good-quality, continuous, simultaneous, and reliable services are provided and presented.

In the global competitive environment, as long as the possibilities of utilization from the information and communication technologies for the applications of Accounting Information System, the function and also the importance of accountancy towards the business managements increase. That Accounting Information System, which provides the production of financial information from the managements, presents the financial-qualified information, which a business management needs in the global competitive environment, inside the digital accounting organization, completely, clearly, timely, and reliably, will enable that the activities of management have a faster, flexible, innovator (reformist), and planned structure.

\section{References}

- $\quad$ Akkaş, Jale, 2000. "Elektronik Ticaret ve Elektronik İş Uygulamaları Muhasebe ve Finansal Raporlamayı Nasıl Etkileyecek ?”, Active Bankacılık ve Finans Dergisi, No:14, Ağustos-Eylül, s.1.

- Alagöz, Ali, 2007. "Web Sitesi Maliyetlerinin Muhasebeleştirilmesi”, Selçuk Üniversitesi Sosyal Bilimler Enstitüsü Dergisi, Sayı:18, s.11.

- Atabey, N.Ata, Parlakkaya, Raif ve Alagöz, Ali, 2006. Genel Muhasebe, Atlas Kitabevi, Konya.

- $\quad$ Bozkurt, Veysel 2000. Elektronik Ticaret, Alfa Yay., Ankara. 
- Canpolat, Ömer. 2001. E-Ticaret ve Türkiye’deki Gelişmeler, T.C. Sanayi ve Ticaret Bakanlığı Tüketicinin ve Rekabetin Korunması Genel Müdürlüğü Yay., Ankara.

- Carter, J., 2002. Developing E-Commerce Systems, Prentice Hall., New Jersey.

- $\quad$ Karataş, N. ve Yılmazsoy, M.,2001. “Sorular ve Cevaplar”, Vergi Dünyası Dergisi, Sayı: 234, ss. $182-183$.

- Karasioğlu, Fehmi, 2001. İnternet Tabanlı Finansal Raporlama, Nobel Yayın Dağıtım, Ankara.

- Özbay, Adem, Devrim, Jan, 2000. E-Ticaret Rehberi, Bilgi Teknolojileri Dizisi 7, Hayat Yayınları, İstanbul.

- Özbay, Sabahat ve Akyazı, Selma, 2004. Elektronik Ticaret, Ankara: Detay Yayıncılık.

- Raif Parlakkaya, 2005. "Elektronik Ticaret ve Muhasebe Uygulamalarına Etkileri”, Selçuk Üniversitesi Karaman İktisadi ve İdari Bilimler Dergisi, Sayı:2, Cilt:5, Aralık. ss.169-170.

- Schoop, Mareike, 2005. "A Language-Action Approach to Electronic Negotiations An International", Journal on Communication, Information Technology and Work, Vol. 1, No. 1, 62-79.

- Semerci, Murat, 2007. Elektronik Ticaretin İşleyişi, Denetimi ve Muhasebeleştirilmesi, Yayınlanmamış Yüksek Lisans Tezi, Sütçü İmam Üniversitesi, Kahramanmaraş.

- $\quad$ Sevim, Adnan, 2009. "Dijital Uygulamaların Muhasebe Eğitimi Üzerine Etkileri, http://www.mu.edu.tr/iibf/tmes24/kitap/2-2.pdf. s.95, 04.01.2009.

- Seyidoğlu, Halil, 20000.Uluslar arası Elektronik Ticaretin Gelişimi, Halil Aksu’ya Armağan Kitabı, İTÜ, İşletme Fak. Yay. İstanbul.

- Şahin, Ali, 2008. Türk Kamu Yönetiminde Yapısal Dönüşüm ve E-Devlet, Çizgi Kitabevi, Konya.

- $\quad$ Torres, Lourdes, Pina, Vicente ve Acerete, Basilio, 2005. "E-goverment Develompent on Delivering Public Services Among EU Cities, Government Information Quarterly, Vol.:22, Issue:2, 217-218.

- $\quad$ Trepper, Charles, 2000. E-Commerce Strategies, Microsoft Pres., Washington.

- WTO(World Trade Organization), 1998. "Study from WTO Secretariat Highlights Potential Trade Gains From Electronic Commerce", http://www.wto.org, 05.01.2004.

- Wurman, P., Walsh, W. ve Wellman, M., 1998. Flexible Double Auctions for Electronic Commerce: Teheory and Implementation, Decision Support Systems.

- Yükçü, Süleyman ve Gönen, Seçkin, 2009. “Türkiye’de Elektronik Ticaretin Muhasebeleştirilmesine İlişkin Uygulama Önerileri”, Atatürk Üniversitesi İktisadi ve İdari Bilimler Dergisi, Cilt: 23, Say1: 2, ss.7-8.

- Yıldız, Fehmi ve Canbaz, Serdar, 2008. “Türkiye’de Elektronik Ticaret Uygulamasında Karşılaşılan Muhasebe Sorunları İle İlgili Bir Araştırma”, Muhasebe ve Finansman Dergisi, Sayı:37, Ocak, s.72.

- Zerenler, Muammer, 2007. Dijital İş Yaşamı: Tüm Boyutlarıyla Elektronik Ticaret, Gazi Kitabevi, Ankara.

- $\quad$ Yenigün, Cüneyt, "Küresel Pazar ve Elektronik Ticaret, 2009. http://www.bilgiyonetimi.org/cm/pages/mkl_gos.php?nt=458, 06.01.2009.

- $\quad$ www.eticaret.org/kavram.htm, 01.04.2009. 